\title{
LC-MS/MS proteomic analysis revealed novel associations of 37 proteins with T2DM and notable upregulation of immunoglobulins
}

\author{
RABAB ASGHAR ABDULWAHAB ${ }^{1,2}$, AYODELE ALAIYA ${ }^{3}$, ZAKIA SHINWARI ${ }^{3}$, \\ ABDUL AMEER A. ALLAITH ${ }^{4}$ and HAYDER A. GIHA ${ }^{5}$ \\ ${ }^{1}$ Integrated Science Division, College of Health Sciences, University of Bahrain, Manama 32038; ${ }^{2} \mathrm{Al}$ Jawhara Centre for \\ Molecular Medicine and Inherited Disorders, Arabian Gulf University, Manama 26671, Kingdom of Bahrain; \\ ${ }^{3}$ Proteomics Unit, Stem Cell and Tissue Re-Engineering Program, King Faisal Specialist Hospital and Research Centre, \\ Riyadh 11211, Saudi Arabia; ${ }^{4}$ Department of Biology College of Science, University of Bahrain, Zallaq 32038; \\ ${ }^{5}$ Department of Medical Biochemistry, College of Medicine and Medical Sciences, \\ Arabian Gulf University, Manama 26671, Kingdom of Bahrain
}

Received November 20, 2018; Accepted March 4, 2019

DOI: $10.3892 /$ ijmm.2019.4127

\begin{abstract}
Type 2 diabetes mellitus (T2DM) is a disease associated with a number of metabolic disturbances, including protein metabolism. In the present study, blood samples were obtained from Bahraini subjects, including 6 patients with T2DM and 6 age- and sex-matched, non-diabetic, healthy controls. Depleted and non-depleted sera were prepared from the collected blood, and the global protein expression changes were evaluated by liquid chromatography tandem mass spectrometry. Only significantly and markedly differentially-expressed proteins $(\mathrm{P}<0.05$, analysis of variance; maximum fold change $\geq 1.5$ ) were considered as candidate proteins for informatics analysis. Accordingly, a total of 62 proteins were identified to be differentially expressed in T2DM, compared with control subjects, and they were grouped functionally into 16 classes of proteins. The largest class was that of the immune-associated proteins. Additionally, 25 of these proteins (40\%) had previously been associated with DM; however, the association of the other 37 proteins with T2DM was a novel observation. The majority of the identified proteins were upregulated in T2DM. The identified proteins could be involved in the pathogenesis of the disease or serve as disease biomarkers. Further validation of the identified proteins in a large study cohort is required, in order to fully access their potential clinical usefulness.
\end{abstract}

Correspondence to: Dr Hayder A. Giha, Department of Medical Biochemistry, College of Medicine and Medical Sciences, Arabian Gulf University, Road 2904, Building 293, Block 329, Manama 26671, Kingdom of Bahrain

E-mail: hayderag@agu.edu.bh

Key words: type 2 diabetes mellitus, proteomics, liquid chromatography tandem mass spectrometry, differential expression, Bahrain

\section{Introduction}

Diabetes mellitus (DM), a chronic metabolic disorder with multiple etiologies, is characterized by hyperglycemia and other metabolic abnormalities attributed to defects in insulin secretion, actions on target tissues or both (1). The global report on diabetes in 2016, reported that type 2 DM (T2DM) affects millions of people globally, including the Middle East (2); in the latter, a high prevalence has been identified in Bahrain, although no recent data has been published (3). In 2015, the International Diabetes Federation estimates indicate that the states of the Gulf Co-operation Council have the highest T2DM rates at a global level (4).

The aim of the present study was to elaborate on the metabolic changes, particularly the blood proteome in T2DM. Proteomics and bioinformatics are complementary molecular tools that have revolutionized biomedical research (5). The robustness of proteomics is enhanced by the continuous upgrading and development of liquid chromatography tandem mass spectrometry (LC-MS/MS) with built-in statistical and graphical software $(6,7)$. Such tools are of the utmost importance for understanding the natural history of multifactorial complex disorders, including cancer, autoimmune diseases and DM. The heterogeneous nature of T2DM (8) makes it a suitable subject for proteomic analysis. However, the applications of proteomics in DM studies to date have fallen short of expectations, as revealed from a literature search. In the present study, LC-MS/MS was used to examine the protein profile of T2DM using serum samples from Bahraini subjects.

The T2DM pathogenesis involves complex interactions between genetic and environmental attributes (8). Insulin resistance is the hallmark of T2DM, although a number of individuals may have normal, decreased or elevated insulin levels (9). Generally, a metabolic malfunction is rarely attributed to a single molecule or etiology, and it is more frequently the combined input of numerous altered molecules, largely proteins. The majority of individuals suffering from T2DM 
have the polygenic heterogeneous variants with multiple genes involved but in different combinations, resulting in different T2DM subsets (8). Therefore, studies that use 'omics' analysis platforms to assess the protein profile changes in T2DM may identify clinically beneficial panels of protein biomarkers. Generally, 'omics' platforms allow for the investigation of more complex interactions of biological systems (10). Proteomics and peptidomics have a number of advantages over genomics, as they investigate a global protein profile that accounts for $>2,000,000$ proteins, compared with the undetermined number of genes (expected to be 20-100,000) (11). The analysis of such a large number of data and variables presents a challenge for 'omics' platforms. Quantitative expression proteomics profiling is expected to advance the understanding of the pathophysiological mechanisms of T2DM, and may generate results demonstrating variations in numerous individual proteins, particularly in communities with a high prevalence of T2DM, such as Bahraini.

T2DM is a systemic disease affecting multiple organs, including skin, liver, kidney and eye (12). Since all tissues come into contact with blood, proteins secreted or leaking from different tissues are reflected in the blood protein profile. The blood is therefore the ideal for proteomic analysis in T2DM. The information regarding these proteins may result in an improved approach for disease prediction and diagnosis, as well as an improved understanding of the disease pathology, and thus a more effective treatment (13). Previously, proteomics profiling of serum and plasma has become a focus of growing interest, and the characterization of their protein content has enabled the discovery of an increasing number of reliable markers indicative of the disease (14). In the present study, label-free quantitative protein expression profiling was used for the discovery of proteins that may potentially serve as biomarkers for T2DM.

\section{Patients and methods}

Study subjects. The peripheral blood samples used in the present study were selected from a larger number of samples collected from Bahraini subjects with T2DM (cases) and healthy individuals (controls) in the period between January and February 2015 for the study of T2DM biomarkers. The samples selected for this study were obtained from 12 subjects, including 6 with T2DM ( 3 males and 3 females) and 6 age-, sex- and ethnic background-matched, healthy, non-diabetic subjects ( 3 males and 3 females) (Table I).

The patients with T2DM were clinically diagnosed according to the World Health Organization criteria (15). The inclusion criteria for cases were: Male or female Bahraini subjects with confirmed T2DM. The exclusion criteria were: Individuals with other metabolic, cancerous or chronic disease, chronic infections, other major diseases, alcoholism/smoking, non-Bahraini subjects or T1DM. The cases were selected randomly from patients reporting to Salmanyia Medical Complex (SMC; Manama, Bahrain). The healthy controls were recruited by an email advertisement sent to the members of College of Health Sciences of Bahrain University (Manama, Bahrain) and extended to their families and friends. The exclusion criteria for the controls were: DM and fasting blood glucose levels of $>5.2 \mathrm{mmol} / \mathrm{l}$, in addition to the exclusion criteria used for cases. All study participants provided their verbal informed consent prior to blood collection. The study design was in compliance with the terms of the Declaration of Helsinki and was approved by the Research and Ethics Committees of Arabian Gulf University and SMC.

Sample collection. Fasting blood samples were collected from all study subjects after 10-12 h of overnight fasting. Subsequently, $\sim 10 \mathrm{ml}$ venous blood samples were collected from peripheral vessels into a heparinized collection tube for plasma and into separation gel tubes (both from Thermo Fisher Scientific, Inc., Waltham, MA, USA) for serum collection. All tubes were gently mixed and centrifuged using a UNIVERSAL 320 (Andreas Hettich GmbH \& Co.KG, Tuttlingen, Germany) (10 min at $3,000 \mathrm{x} \mathrm{g}$ at $25^{\circ} \mathrm{C}$ ) for serum separation. The plasma was separated using Ficoll gradient centrifugation (10 min at 3,000 x g at $25^{\circ} \mathrm{C}$ ). Serum was used for lipid analysis and stored as aliquots at $-80^{\circ} \mathrm{C}$ for later use in protein profiling. Plasma was used for fasting glucose concentration measurements and stored as aliquots at $-80^{\circ} \mathrm{C}$ for other experiments.

\section{Biochemical tests}

Blood glucose and glycated hemoglobin (HbAlc) determination. Blood glucose levels were analyzed using Clinical Analyzer Roche COBAS Integra ${ }^{\circledR} 800$ (Roche Applied Science, Rotkreuz, Switzerland). The results were expressed using SI units (mmol/l).

The assay for HbA1c measurement involved the use of four reagents: Total $\mathrm{Hb}, \mathrm{HbA1c} \mathrm{R} 1$ antibody and HbA1c R2 agglutinate reagents, and $\mathrm{Hb}$ denaturant (Beckman Coulter, Inc., Brea, CA, USA). The ratio of HbA1c to total $\mathrm{Hb}$ was expressed as a percentage, HbA1c $\%$.

Serum lipid profile. The lipid profile parameters, including total cholesterol, triglyceride, and low-and high-density lipoprotein cholesterol, were measured at the SMC Biochemistry Laboratory using Clinical Analyzer Roche COBAS Integra 800 (Roche Applied Science).

\section{Protein profiling using $L C-M S / M S$}

Protein depletion and serum preparation. To overcome the serum protein complexity, human serum albumin (HSA) and the major subclasses of $\gamma$ globulin ( $\mathrm{IgG}$ ) were removed from the serum. Pierce Albumin/IgG Removal kit (Thermo Fisher Scientific, Inc.) was used and the depletion protocol was followed according to the manufacturer's protocols. The filtrate containing the sample depleted from HSA and IgG subclasses was considered a depleted sample, and the unprocessed serum a non-depleted sample. The proteins were precipitated using $1 \mathrm{M} \mathrm{NaCl}$. The depleted samples were concentrated using Amicon ${ }^{\circledR}$ Ultra-0.5 Centrifugal Filter Devices (EMD Millipore, Billerica, MA, USA). The non-depleted samples were first desalted with $1 \mathrm{M} \mathrm{NaCl}$ and then concentrated similar to the depleted samples.

Protein determination. The Bradford method (16) was used to determine the exact quantity of proteins in the serum, in order to calculate the amount of sample required for protein analysis, a prerequisite for LC-MS/MS analysis. Briefly, the assay was performed in a 96-well micro-titer plate. The stock solution used for this assay contained bovine serum albumin (BSA; Sigma-Aldrich; Merck KGaA, Darmstadt, Germany) 
Table I. Clinical, biochemical and demographic characteristics of the study subjects.

\begin{tabular}{lcccccccccc}
\hline Serial no. & Sample ID & $\begin{array}{c}\text { Clinical } \\
\text { diagnosis }\end{array}$ & Sex & $\begin{array}{c}\text { Age } \\
(\text { years })\end{array}$ & $\begin{array}{c}\text { Glucose } \\
(\mathrm{mmol} / \mathrm{l})\end{array}$ & $\begin{array}{c}\text { HbA1c } \\
(\%)\end{array}$ & $\begin{array}{c}\text { LDLC } \\
(\mathrm{mmol} / \mathrm{l})\end{array}$ & $\begin{array}{c}\text { HDLC } \\
(\mathrm{mmol} / \mathrm{l})\end{array}$ & $\begin{array}{c}\text { TGs } \\
(\mathrm{mmol} / \mathrm{l})\end{array}$ & $\begin{array}{c}\text { T CHOL } \\
(\mathrm{mmol} / \mathrm{l})\end{array}$ \\
\hline 1 & M1 & T2DM & F & 42 & 6.3 & 49 & 3.6 & 1.3 & 1.8 \\
2 & S4 & Control & F & 42 & 5.7 & ND & 3.3 & 1.5 & 1.2 & 5.3 \\
3 & M18 & T2DM & F & 41 & 7.2 & 30 & 3.3 & 1 & 1.7 & 5.1 \\
4 & S8 & Control & F & 41 & 5.4 & ND & 2.5 & 1.7 & 1 & 4.7 \\
5 & ES12 & T2DM & F & 47 & 7.4 & 71 & 4.4 & 1 & 1.6 & 6.1 \\
6 & SR & Control & F & 47 & 4.9 & ND & 3.73 & 1.6 & 0.8 & 5.7 \\
7 & ES27 & T2DM & M & 42 & 7.3 & 53 & 3.6 & 0.9 & 1.4 & 5.1 \\
8 & S52 & Control & M & 42 & 5.1 & ND & 2.5 & 0.98 & 1.4 & 4.1 \\
9 & ES29 & T2DM & M & 41 & 6.9 & 44 & 1.8 & 0.9 & 2.8 & 4 \\
10 & S15 & Control & M & 41 & 4.9 & ND & 3.1 & 1.2 & 0.4 & 4.5 \\
11 & S75 & T2DM & M & 47 & 12.1 & 89 & 4.4 & 1 & 1.5 \\
12 & SK & Control & M & 47 & 5.5 & ND & 3.2 & 0.9 & 1.7
\end{tabular}

LDLC, low density lipoprotein cholesterol; HbA1c, glycated hemoglobin; HDLC, high density lipoprotein cholesterol; TGs, triglycerides; T CHOL, total cholesterol; ND, not done; T2DM, type 2 diabetes mellitus; M, male; F, female.

as Stock I, 1:10 (v/v) RapiGest ${ }^{\mathrm{TM}}$ SF (Waters Corporation, Milford, MA, USA) as Stock II and 1:100 (v/v) RapiGest SF as blank solution. A set of 8 diluted BSA standards $(0.50,0.85$, $1.40,2.40,4.00,7.00,11.80$ and $20.00 \mu \mathrm{g} / 100 \mu \mathrm{l})$ in a final volume of $50 \mathrm{ml}$ with Stock 1 were prepared. The absorbance for the samples was measured at $590 \mathrm{~nm}$ using a spectrophotometer (Bio-Rad Laboratories, Inc., Hercules, CA, USA). The estimated protein concentration for each sample was determined using a standard curve.

All serum samples were diluted at a 1:1 ratio with $0.1 \%$ RapiGest SF prior to protein determination assay, in order to achieve a protein concentration for the diluted samples within the working range of the standards $(0.5-20 \mu \mathrm{g} / \mu \mathrm{l})$. The RapiGest SF solution was prepared from $50 \mathrm{mM}$ ammonium bicarbonate (AmBic), bezamidine and $20 \mathrm{mM}$ phenylmethylsulfonyl fluoride (all from Sigma-Aldrich; Merck KGaA). The diluted samples were stored at $-80^{\circ} \mathrm{C}$ prior to protein analysis.

In-solution protein digestion prior to $L C-M S / M S$. For LC-MS/MS analysis, the non-depleted and depleted sera were diluted at a $1: 1$ ratio with $0.1 \%$ RapiGest SF and study samples were pooled together. Accordingly, the duplicates of the 12 sera samples (12 depleted and 12 non-depleted) were each pooled into 4 sets of samples (T2DM males/females and control males/females). The total load for each pooled sample used for analysis was $100 \mu \mathrm{g}$ in a final volume of $25 \mu \mathrm{l}$. The volume of each sample to be included in the pooled sample was calculated from the protein concentration in each sample. The final volume was achieved by adding $0.1 \%$ RapiGest SF in $50 \mathrm{mM}$ AmBic solution. The proteins in the pooled samples were denatured at $80^{\circ} \mathrm{C}$ for $15 \mathrm{~min}$ in a Thermo-mixer $\mathrm{R}$ (Eppendorf, Hamburg, Germany) at a speed of $8 \times \mathrm{g}$. The denatured proteins were reduced by $100 \mathrm{mM}$ dithiothreitol at $60^{\circ} \mathrm{C}$ for $30 \mathrm{~min}$ and then alkylated by $200 \mathrm{mM}$ iodoacetamide (both from Sigma-Aldrich; Merck KGaA) at room temperature for $40 \mathrm{~min}$ in the dark. Finally, the proteins were digested using Trypsin at a 1:50 ratio (Promega Corporation, Madison, WI, USA). The samples were incubated at $37^{\circ} \mathrm{C}$ over- night in an Eppendorf Thermo-mixer R (8 x g). Subsequently, the digestion was stopped by acidification $\left(12 \mathrm{M} \mathrm{HCl}\right.$ at $37^{\circ} \mathrm{C}$ for $15 \mathrm{~min})$ and centrifugation $\left(15,682 \mathrm{x} \mathrm{g}\right.$ at $4^{\circ} \mathrm{C}$ for $\left.10 \mathrm{~min}\right)$. The samples were diluted at a 1:1 ratio with the dilution solution ( $1 \%$ acetonitrile, $0.1 \%$ formic acid and $99 \% \mathrm{H}_{2} \mathrm{O} \mathrm{LC} / \mathrm{MS}$ grade). The protein digest was then analyzed using Synapt G2 MS (Waters Corporation).

Protein identification by LC-MS/MS. Label-free quantitative expression protein profiling was performed using 1-dimensional Nano Acquity liquid chromatography coupled with LC-MS/MS on a Synapt G2 instrument (Waters Corporation). The instrument settings for electrospray ionization MS analysis were optimized on the tune page, as previously described $(17,18)$. Briefly, detectors set up was adjusted using $0.5 \mathrm{ng} / \mu$ l leucine-enkephalin (556.277 Da). Mass (m/z) calibration was achieved on a separate infusion of 500 fmol Glu-fibrinopeptide B (785.843 Da), using the Mass Lynx 4.1 SCN870. The setting of other parameters was as follows: Capillary voltage $3.5 \mathrm{kV}$, sample cone $35 \mathrm{~V}$, extraction cone $4 \mathrm{~V}$, source temperature $85^{\circ} \mathrm{C}$, cone gas $10 \mathrm{l} / \mathrm{h}$, Nano flow gas 0.6 bar and purge gas $600 \mathrm{l} / \mathrm{h}$. All analyses were conducted on Trizaic Nano source (Waters Corporation).

A total of $3 \mu \mathrm{g}$ protein digest was loaded on LC-MS/MS column and all samples were spiked with yeast alcohol dehydrogenase (Sigma-Aldrich; Merck KGaA) as an internal standard to the digests, to provide 200 fmol per injection for absolute quantitation. All the analyzed samples were processed using the Acquity sample manager with mobile phase consisting of A1 (99\% water, $0.1 \%$ formic acid and $1 \%$ acetonitrile) and B1 ( $100 \%$ acetonitrile and $0.1 \%$ formic acid) solutions with a sample flow rate of $0.500 \mu \mathrm{l} / \mathrm{min}$. Data independent acquisition (DIA) and ion mobility separation experiments were performed, and data was acquired over a range of $\mathrm{m} / \mathrm{z}$ 50-2,000 Da with a scan time of $1 \mathrm{sec}$, at a ramped transfer collision energy of 25-50 V with a total acquisition time of $120 \mathrm{~min}$ in DIA analysis. All peptides within a defined $\mathrm{m} / \mathrm{z}$ range were subjected to fragmentation, resulting in accurate protein quantification. 
The samples were analyzed in duplicate and data were acquired using Mass Lynx software (version 4.1, SCN870; Waters Corporation) operated in resolution and positive polarity modes. The acquired MS data were background-subtracted, smoothed and de-isotoped at a medium threshold. Progenesis QI V2.0 (QIfp) for proteomics (Nonlinear Dynamics; Waters Corporation) was used for automated data processing and database searching. The generated peptide masses were searched against UniProt protein sequence database using the Progenesis QI V2.0 (QIfp) for proteomics, for protein identification and quantification (Nonlinear Dynamics; Waters Corporation).

Data analysis and informatics. The comparisons were made between the mean \pm standard error of the mean values of the readings of each subset of samples, such as the depleted samples of T2DM males and female vs. the controls. The Progenesis QI V2.0/TransOmics Informatics (Waters Corporation) software was used to process and search the data using the principle of the search algorithm, as previously described $(19,20)$. The data were filtered to show only statistically significant $[\mathrm{P}<0.05$; analysis of variance (ANOVA) and post hoc Tukey's test] changes in protein concentration with maximum fold change $(\mathrm{MFC}) \geq 1.5$. Normalized label-free quantification was achieved to plot principal component analysis against data split into two groups (data not shown). Hierarchical Cluster Analysis of the expression profiles of the test samples between all (males and females) controls and T2DM subjects was conducted and Bray Curtis Correlation distance metric and an average linkage clustering method from the J-Express Pro V1.1 software (java.sun.com) was used to generate dendrograms. $\mathrm{P} \leq 0.05$ was considered to indicate a statistically significant difference. For classification of the identified proteins, the UniProt database (https://www.uniprot.org/) and PANTHER Class Information (http://www.pantherdb.org/panther/category.do?categoryAcc=GO:0030234) were the bioinformatics tools used. PubMed (https://www.ncbi.nlm.nih.gov/pubmed) was used for searching the literature for the association of each of the identified proteins with DM (any type) and insulin resistance, if no publication was located, the association of that protein with any other disorder was searched for.

\section{Results}

Total and differentially-expressed proteins in non-depleted and depleted sera. LC-MS/MS identified $\sim 1,400,000$ proteins/peptides in non-depleted sera and $\sim 2,400,000$ in depleted sera from healthy non-diabetic subjects (controls) and patients with T2DM (cases). From the non-depleted samples, 117 proteins exhibited significantly different expression changes between cases and controls $(\mathrm{P}<0.05$; ANOVA). Of the 117 identified differentially-expressed proteins, only 43 exhibited a significantly marked difference $(\mathrm{MFC} \geq 1.5, \mathrm{P}<0.05)$ between the 2 groups. By contrast, the levels of 168 proteins in the depleted samples were significantly different between patients and controls $(\mathrm{P}<0.05)$, and of the 168 , only 23 proteins differed markedly $(\mathrm{MFG} \geq 1.5)$. However, 4 of the proteins with $\mathrm{MFC} \geq 1.5$ and $\mathrm{P}<0.05$ were detected in both depleted and non-deleted datasets (data not shown).
Markedly differentially-expressed proteins in T2DM in the analysis of non-depleted sera samples. As detailed in Table II, of the 43 proteins with $\mathrm{MFG} \geq 1.5$ and $\mathrm{P}<0.05$ in non-depleted samples, 29 were upregulated and 14 downregulated in T2DM, compared with control samples. The most upregulated proteins $(\mathrm{P}<0.001)$ were $\alpha-1$-acid glycoprotein $2, \operatorname{Ig} \mu$ chain $\mathrm{C}$ region, Ig $\gamma-3$ chain $C$ region, thrombin light chain, and heparin cofactor 2, while the most downregulated proteins were $\operatorname{Ig} \gamma-4$ chain $\mathrm{C}$ region, and ribulose-5-phosphate-3-epimerase isoform CRA_a.

Details on the expression changes, and protein characteristics and descriptions are presented in Table II. The peptide count range of the upregulated proteins was 1-35 peptides [mean \pm standard deviation (SD), $10.1 \pm 8.2$ peptides; median, 9.0 peptides; $25-75 \%$, 3.0-16.3 peptides] and the unique peptide range was 1-32 peptides (mean $\pm \mathrm{SD}, 4.8 \pm 6.4$ peptides; median, 3.0 peptides; $25-75 \%$, 1.0-5.0 peptides). The peptide count range of the downregulated proteins was $1-19$ peptides (mean $\pm \mathrm{SD}, 4.7 \pm 5.4$ peptides; median, 2.0 peptides; $25-75 \%$, 1.3-7.0 peptides), and the unique

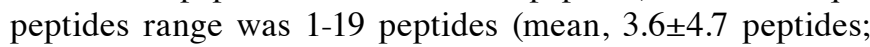
median, 2.0 peptides; $25-75 \%$, 1.0-3.0 peptides). The expression changes, upregulation, including proline rich coiled-coil $2 \mathrm{~B}$ and $\alpha-1$-acid glycoprotein 2 , and downregulation, including apolipoprotein C-II and suppression of tumorigenicity 5 protein, of a number of these proteins between subjects with T2DM and non-diabetic subjects $(\mathrm{P}<0.05$, ANOVA) are depicted in Fig. 1A-F and G-L, respectively. As depicted in Fig. 2, the expression levels of 30 differentially-expressed proteins $(\mathrm{P}<0.05$, ANOVA; $M F C \geq 1.5$ ), including heparin cofactor 2 , Ig $\alpha-1$ chain $C$ region, zinc- $\alpha$-2-glycoprotein and inter- $\alpha$-trypsin inhibitor heavy chain H1, among all 4 study groups, (T2DM males/females and control males/females) were subjected to Hierarchical Cluster Analysis, which separates the samples into two distinct clusters, cases and controls,

Markedly differentially expressed proteins in T2DM in the analysis of depleted sera samples. Using the depleted sera, 23/168 proteins were markedly differentially expressed, including 15 up- and 8 downregulated proteins in T2DM, compared with control samples. These changes were considered significant based on the ANOVA results $(\mathrm{P}<0.05$; Table III). Among the most upregulated proteins in the depleted samples from T2DM subjects $(\mathrm{P}<0.001)$ were vitronectin, $\mathrm{Hb}$ subunit $\delta$ and apolipoprotein B-100. Additionally, the most downregulated protein in T2DM was CD5 antigen-like protein $(\mathrm{P}=0.0087)$.

Details on expression changes, and protein characteristics and descriptions are presented in Table III. The peptide count range of the upregulated proteins was $1-16$ peptides (mean $\pm \mathrm{SD}$, 4.3 \pm 4.1 peptides; median, 3 peptides; $25-75 \%$, 1.3-5.5 peptides) and the unique peptides range was $1-16$ peptides (mean $\pm \mathrm{SD}, 3.4 \pm 3.7$ peptides; median, 3 peptides; $25-75 \%$, 1.0-4.0 peptides). The peptide count range of the downregulated proteins was $1-16$ peptides (mean $\pm \mathrm{SD}, 4.7 \pm 5.4$ peptides; median, 2.0 peptides; $25-75 \%$, $1.3-7.0$ peptides), and the unique peptides range was $1-6$ peptides (mean \pm SD, 3.9 \pm 2.1 peptides; median, 4.0 peptides; $25-75 \%$, 2.0-6.0 peptides).

The difference in expression levels (up- and downregulation) of a number of these proteins between subjects with T2DM and control subjects, are depicted in Fig. 3A-F and G-L, respectively. The expression levels of 9 differentially-expressed 


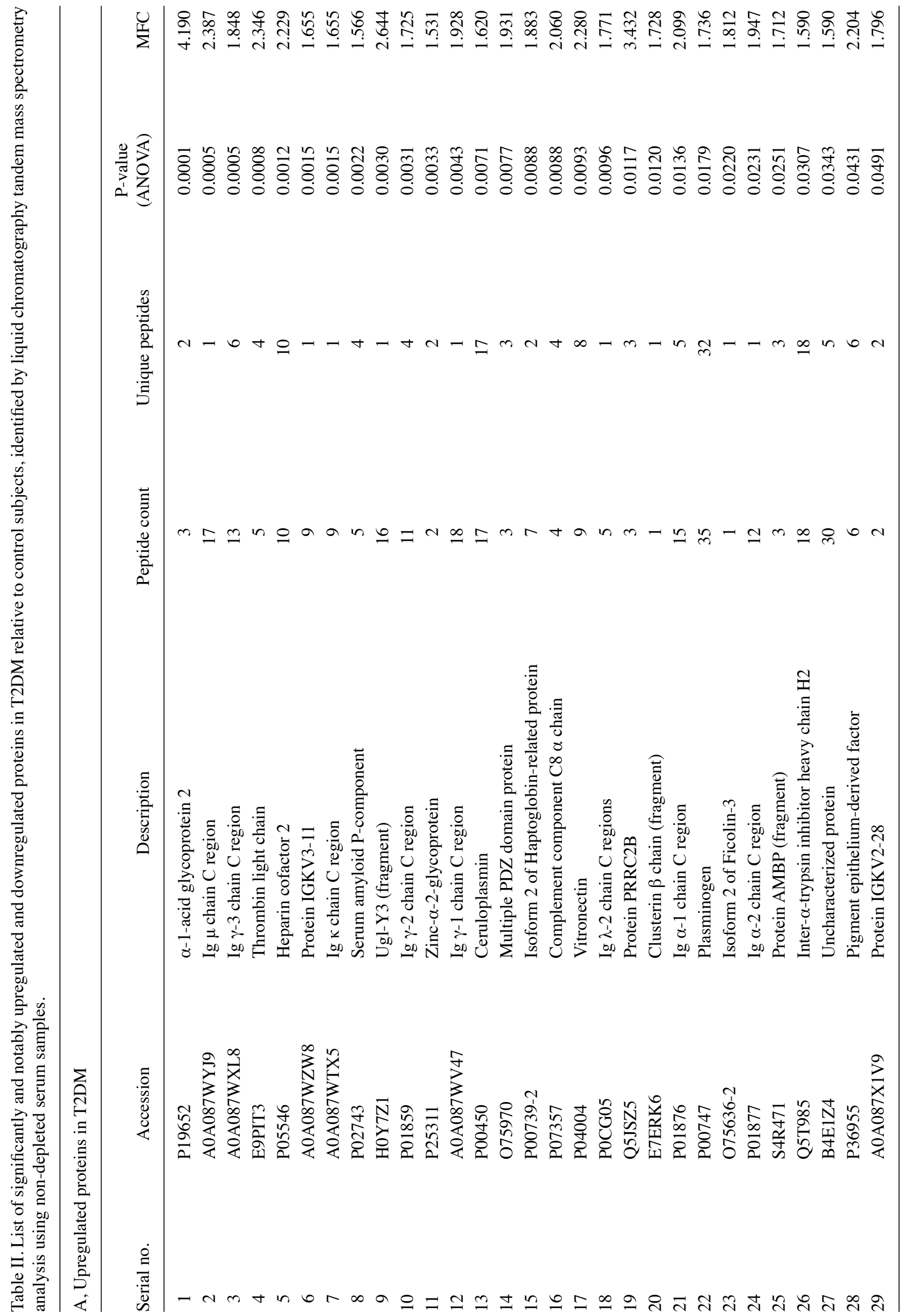




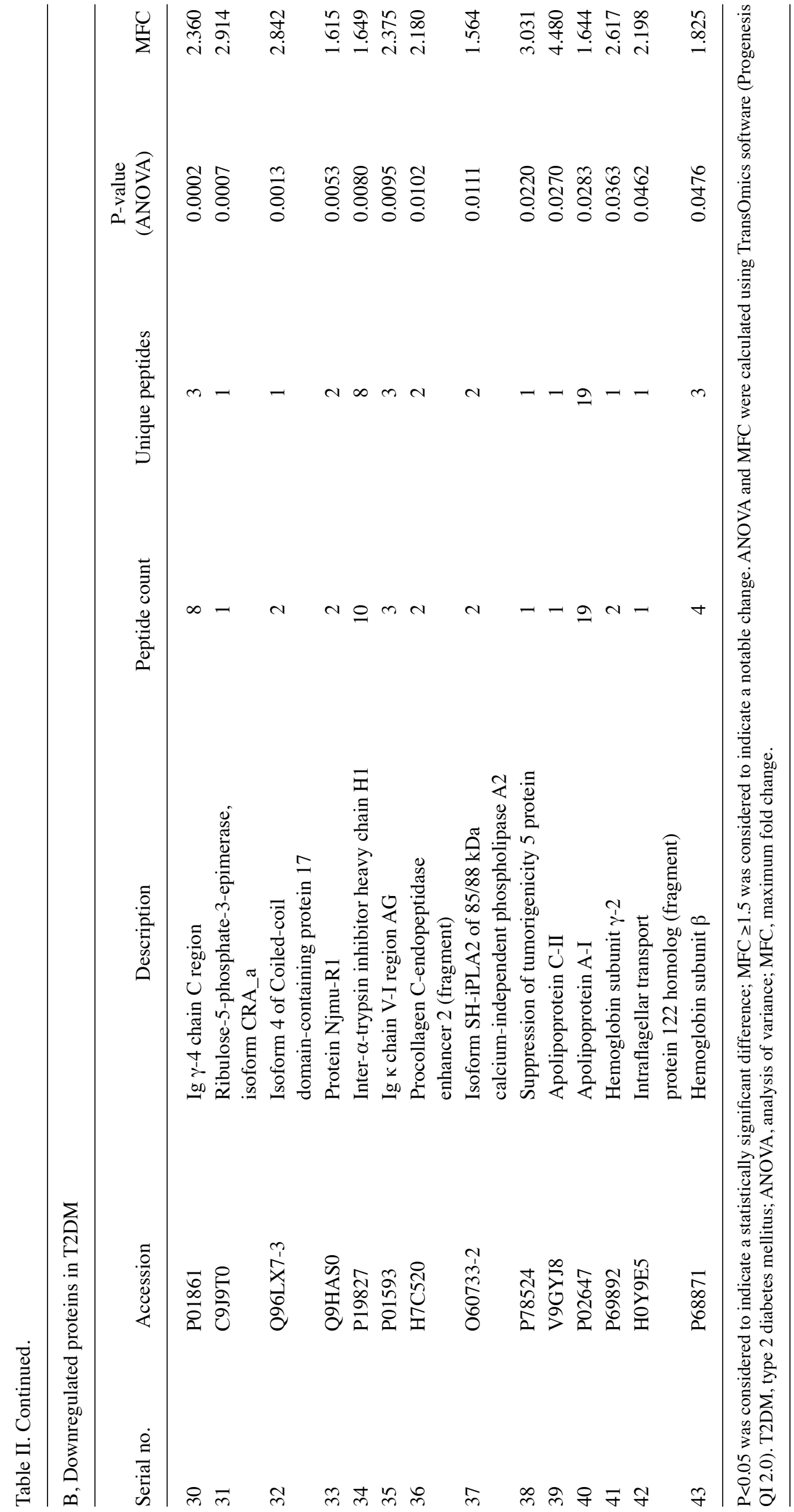



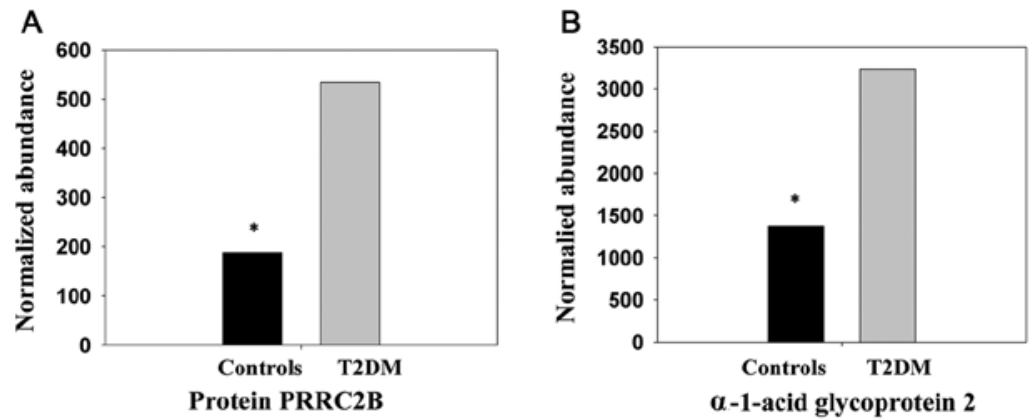

E

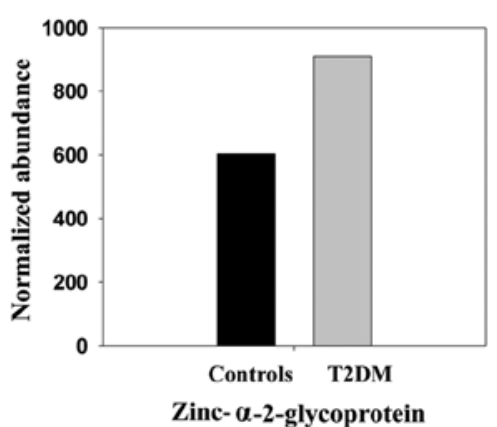

G

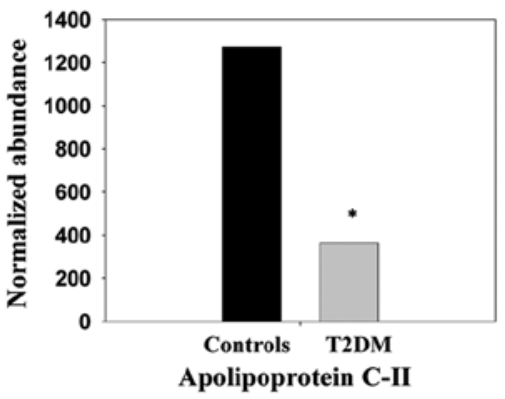

J

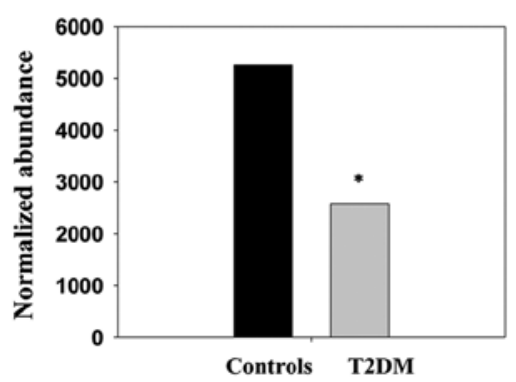

Procollagen C-endopeptidase enhancer 2

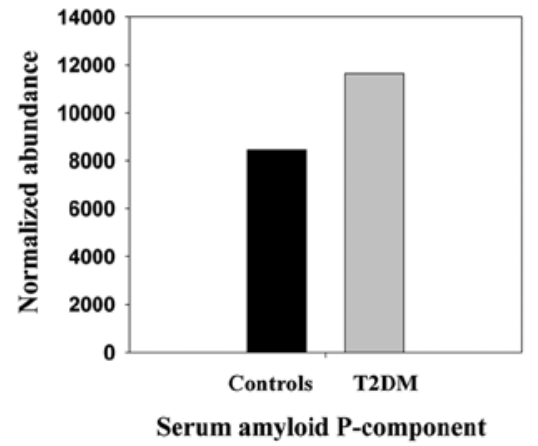

$\mathrm{H}$

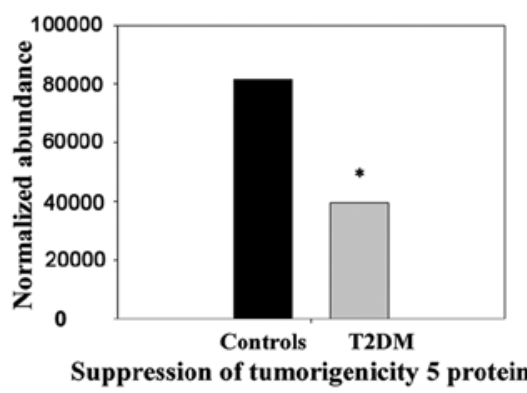

K

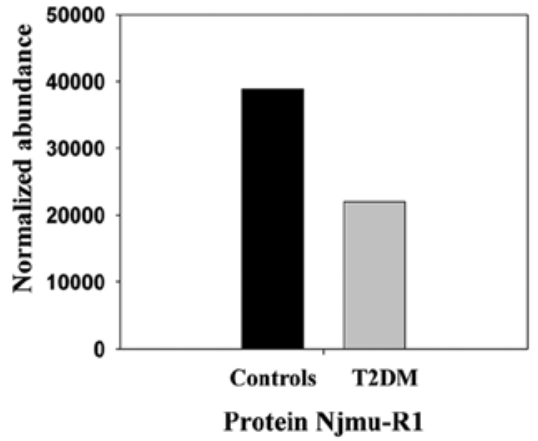

C

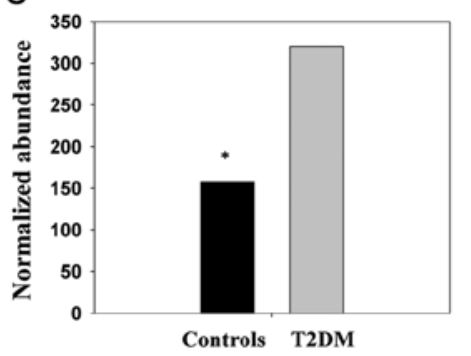

Isoform 2 of haptoglobin-related protein

F

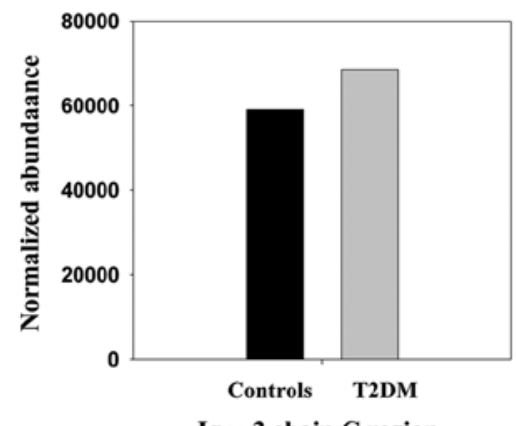

$\operatorname{Ig} \gamma-3$ chain $C$ region

I

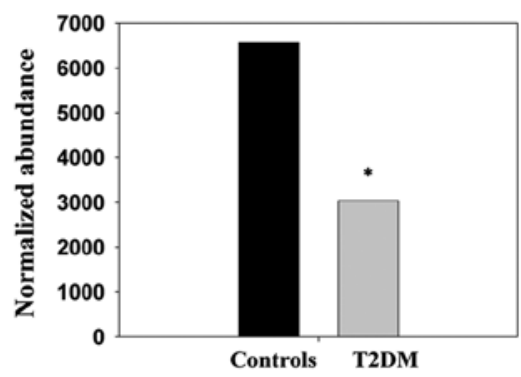

Intraflagellar transport protein 122 homolog

L

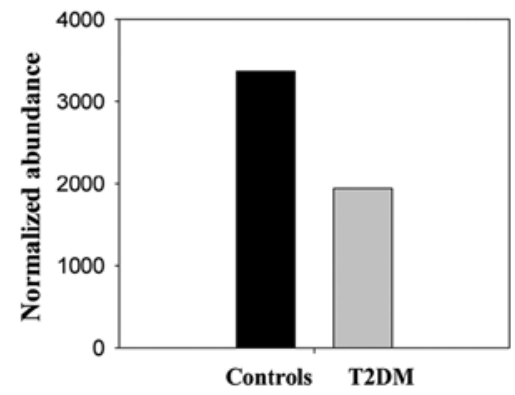

Isoform SH-iPLA2 of 85/88 kDa calcium-independent phospholipase A2

Figure 1. Histograms of the normalized abundance of selected differentially-expressed proteins (highest and lowest) identified in non-depleted serum samples from patients with T2DM (males and females together) and normal control subjects (males and females together). The expression changes of (A-F) upregulated and (G-L) downregulated proteins in T2DM, compared with the control, are indicated. The differences between T2DM subjects and controls for the upregulated proteins, including $(\mathrm{A})$ protein $\mathrm{PRRC} 2 \mathrm{~B}(\mathrm{P}=0.012)$, (B) $\alpha$-1-acid glycoprotein $2(\mathrm{P}<0.001)$ and $(\mathrm{C})$ isoform 2 of Haptoglobin-related protein $(\mathrm{P}=0.009)$, and downregulated proteins, including $(\mathrm{G})$ apolipoprotein $\mathrm{C}-\mathrm{II}(\mathrm{P}=0.027),(\mathrm{H})$ suppression of tumorigenicity 5 protein $(\mathrm{P}=0.022)$, (I) intraflagellar transport protein 122 homolog (fragment) $(\mathrm{P}=0.046)$, and $(\mathrm{J})$ procollagen $\mathrm{C}$-endopeptidase enhancer 2 (fragment) $(\mathrm{P}=0.01)$, were significant $(" \mathrm{P}<0.05)$, according to analysis of variance. The other proteins D-F, $\mathrm{K}$ and $\mathrm{L}$ were comparable between the cases and the controls. The proteins were identified using label-free quantified liquid chromatography tandem mass spectrometry on Synapt G2 analysis. The expression levels of (A-L) all proteins were significantly different between T2DM subjects and controls when males and females compared separately. T2DM, type 2 diabetes mellitus.

proteins ( $\mathrm{P}<0.05$, ANOVA; MFC $\geq 1.5$ ), including importin-8 and plasma protease $\mathrm{C} 1$ inhibitor, among all 4 study groups, (T2DM males/females and control males/females) was subjected to Hierarchical Cluster Analysis, which separates the samples into two distinct clusters, cases and controls, as depicted in Fig. 4. 


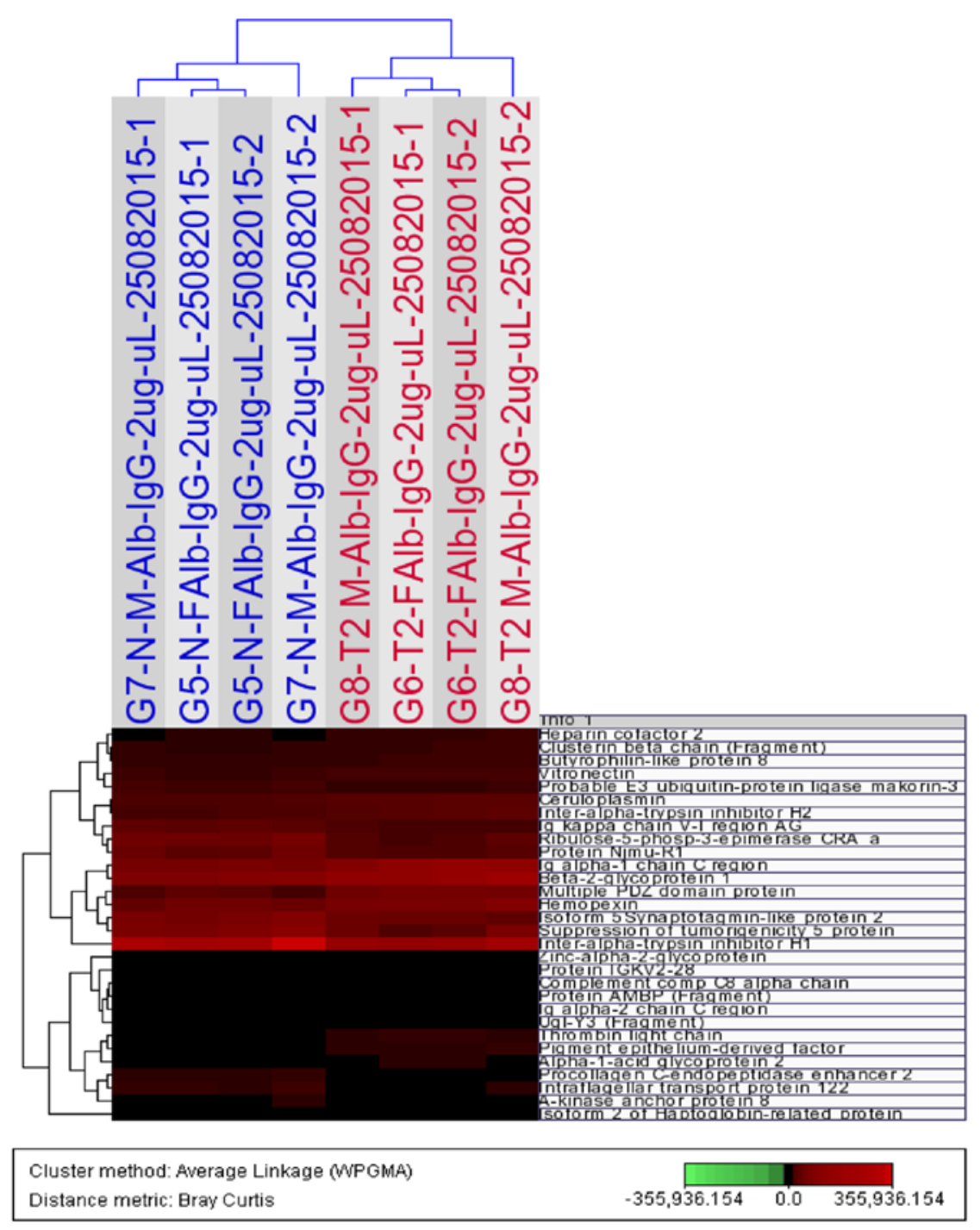

Figure 2. Hierarchical Cluster Analysis of the expression profiles of non-depleted serum samples using 30 proteins that differ significantly $(\mathrm{P}<0.05$, analysis of variance; maximum fold change $\geq 1.5$ ) between all controls (males and females; blue) subjects and all subjects with type 2 diabetes mellitus (red). The dendrogram was generated using the Bray Curtis Correlation distance metric and an average linkage clustering method from the J-Express Pro V1.1 software (java.sun.com).

Functional classification of the differentially-expressed proteins. The UniProt database, being one of the reliable sources (21) for the biological and/or molecular functions of the identified differentially-expressed proteins, was searched. The 62 identified proteins could be categorized into multiple sub-classes. The largest class was that of immune system-associated proteins, consisting of 18 proteins, which included 13 different types of Igs [11 Ig chain $\mathrm{C}$ regions $(6 \gamma$, $2 \alpha, 1 \kappa, 1 \lambda$ and $1 \mu$ ), 2 Ig chain V regions ( 1 Ig $\kappa$ chain V-I region AG and 1 Protein IGKV2-28)], and 5 were proteins with variable immune functions (Table IV). The majority $(83 \%, 15 / 18)$ of the proteins in this class were upregulated in T2DM, compared with the control samples. The other classes were enzyme regulators (6 proteins), $\mathrm{Hb}$ chains and $\mathrm{Hb}$-associated proteins (5 proteins), catalytic proteins (4 proteins) and cell adhesion proteins (4 proteins). Additional classes of proteins identified included signal transduction (4 proteins), transport ( 3 proteins), lipid metabolism and apolipoproteins ( 3 proteins), blood coagulation ( 2 proteins) and regulatory ( 2 proteins) classes. In the remaining classes of proteins, including cytoskeletal, secretory, RNA-binding and spermatogenesis, only 1 protein was identified in each class. Additionally, classes of 7 proteins were not identified. However, functionally, a number of proteins could belong to more than one class

Association of the identified proteins with DM and development of T2DM protein panel. A literature search on PubMed was performed to determine the association between the 62 identified proteins and DM. It was determined that 25 proteins have been previously reported to be associated with DM. Of these proteins, 8 (apolipoprotein A-I, plasminogen, pigment epithelium-derived factor, serum amyloid P-component, apolipoprotein B-100, ceruloplasmin, transthyretin and $\alpha-1$-acid glycoprotein 28) had previously been thoroughly investigated in DM (each reported in $>300$ articles at the time of the search). Furthermore, 3 proteins (vitronectin, myosin light chain 5 and apolipoprotein C-II) had been frequently investigated in DM (100-300 articles), and 6 proteins (Hb subunit $\alpha$, heparin cofactor 2 , zinc- $\alpha$-2-glycoprotein, Ig $\kappa$ chain $C$ region, multiple 
Table III. List of significantly and markedly upregulated and downregulated proteins in T2DM relative to control subjects, identified by liquid chromatography tandem mass spectrometry analysis using depleted serum samples.

A, Upregulated proteins in T2DM

\begin{tabular}{|c|c|c|c|c|c|c|}
\hline Serial no. & Accession & Description & $\begin{array}{l}\text { Peptide } \\
\text { count }\end{array}$ & $\begin{array}{l}\text { Unique } \\
\text { peptides }\end{array}$ & $\begin{array}{c}\text { P-value } \\
\text { (ANOVA) }\end{array}$ & MFC \\
\hline 1 & P04004 & Vitronectin & 2 & 1 & 0.0005 & 2.912 \\
\hline 2 & P02042 & Hemoglobin subunit $\delta$ & 8 & 2 & 0.0005 & 2.051 \\
\hline 3 & A8MUN2 & Apolipoprotein B-100 & 16 & 16 & 0.00089 & 1.518 \\
\hline 4 & C9J7Z6 & $\begin{array}{l}\text { Eukaryotic translation initiation } \\
\text { factor } 4 \mathrm{E} \text { type } 3 \text { (fragment) }\end{array}$ & 3 & 3 & 0.00148 & 2.030 \\
\hline 5 & A0A087 & $\begin{array}{l}\text { Multiple epidermal growth factor-like } \\
\text { domains protein } 11 \text { (fragment) }\end{array}$ & 1 & 1 & 0.00169 & 1.830 \\
\hline 6 & P69905 & Hemoglobin subunit $\alpha$ & 9 & 3 & 0.0030 & 2.040 \\
\hline 7 & Q08380 & Galectin-3-binding protein & 4 & 4 & 0.00861 & 1.698 \\
\hline 8 & Q30KQ8 & $\beta$-defensin 112 & 1 & 1 & 0.01019 & 1.782 \\
\hline 9 & D6RA88 & Myosin light chain 5 & 1 & 1 & 0.0132 & 2.193 \\
\hline 10 & P02766 & Transthyretin & 6 & 5 & 0.0175 & 3.053 \\
\hline 11 & Q9Y4G8 & $\begin{array}{l}\text { Rap guanine nucleotide } \\
\text { exchange factor } 2\end{array}$ & 4 & 4 & 0.0187 & 1.553 \\
\hline 12 & Q96J01 & THO complex subunit 3 & 3 & 3 & 0.02369 & 1.662 \\
\hline 13 & O95342 & Bile salt export pump & 4 & 4 & 0.0391 & 1.627 \\
\hline 14 & O15397 & Importin-8 & 1 & 1 & 0.0437 & 1.555 \\
\hline 15 & Q5VU13 & $\begin{array}{l}\text { V-set and immunoglobulin } \\
\text { domain-containing protein } 8\end{array}$ & 2 & 2 & 0.04537 & 2.090 \\
\hline
\end{tabular}

B, Downregulated proteins in T2DM

\begin{tabular}{lllrrr}
\hline Serial no. & Accession & Description & $\begin{array}{c}\text { Peptide } \\
\text { count }\end{array}$ & $\begin{array}{c}\text { Unique } \\
\text { peptides }\end{array}$ & $\begin{array}{c}\text { P-value } \\
\text { (ANOVA) }\end{array}$ \\
\hline 16 & O43866 & CD5 antigen-like & 6 & 6 & 0.0087 \\
17 & A0A087WXL8 & Ig $\gamma$-3 chain C region & 17 & 6 & 0.0102 \\
18 & P05155 & Plasma protease C1 inhibitor & 3 & 3 & 0.0179 \\
19 & P01859 & Ig $\gamma$-2 chain C region & 14 & 6 & 0.0218 \\
20 & H3BTQ6 & TATA box-binding protein-associated & 5 & 2.638 \\
21 & & factor RNA polymerase I subunit C & & 0.0229 \\
22 & Q5TAQ9 & DDB1- and CUL4-associated factor 8 & 5 & 1.547 \\
23 & P01861 & Ig $\gamma$-4 chain C region & 7 & 5 & 0.02439 \\
\hline
\end{tabular}

$\mathrm{P}<0.05$ was considered to indicate a statistically significant difference; MFC $\geq 1.5$ was considered to indicate a notable change. ANOVA and MFC were calculated using TransOmics software (Progenesis QI 2.0). T2DM, type 2 diabetes mellitus; ANOVA, analysis of variance; MFC, maximum fold change.

PDZ domain protein and Rap guanine nucleotide exchange factor 2) had been less investigated. Finally, 8 proteins, including protein AMBP, complement component $\mathrm{C} 8 \alpha$ chain, CD5 antigen-like, $\operatorname{Ig} \lambda-2$ chain $C$ regions, clusterin $\beta$ chain, eukaryotic translation initiation factor $4 \mathrm{E}$ type 3 , suppression of tumorigenicity 5 protein and bile salt export pump, had been infrequently reported in association with DM ( $<5$ articles). The PubMed search did not reveal any study for DM with the remaining 37/62 proteins (Tables II and III). These 37 proteins are thus a potential 'novel T2DM-protein-panel' that requires further verification.

\section{Discussion}

DM is a classic metabolic disorder, during which the metabolism is frequently disturbed and metabolic homeostasis is disarranged, due to lack or reduction of the insulin action (22). Insulin is a major regulator of metabolism in all 
A

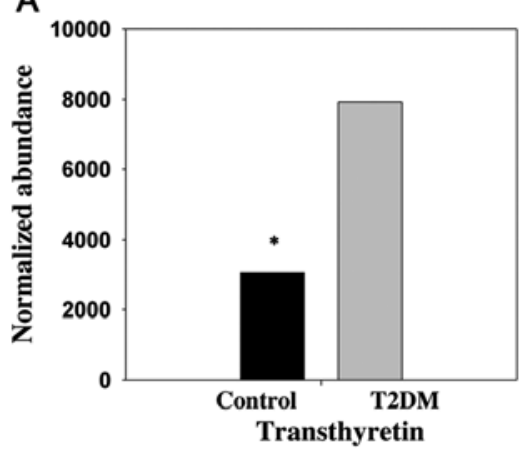

D

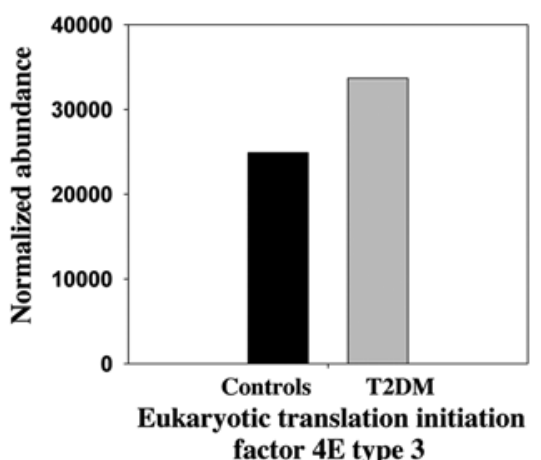

G

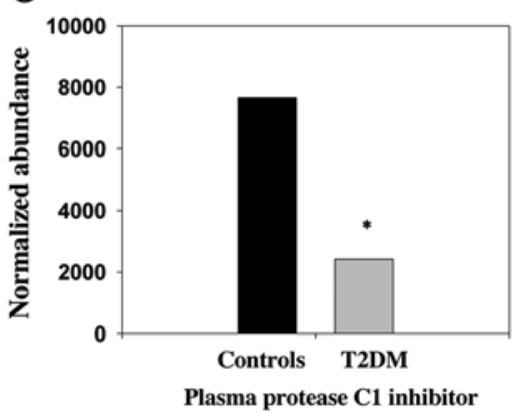

J

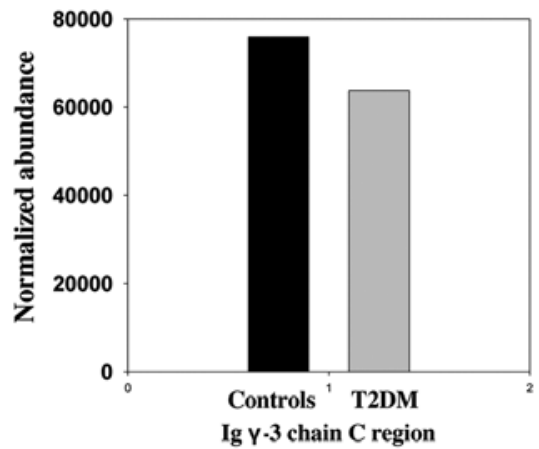

B

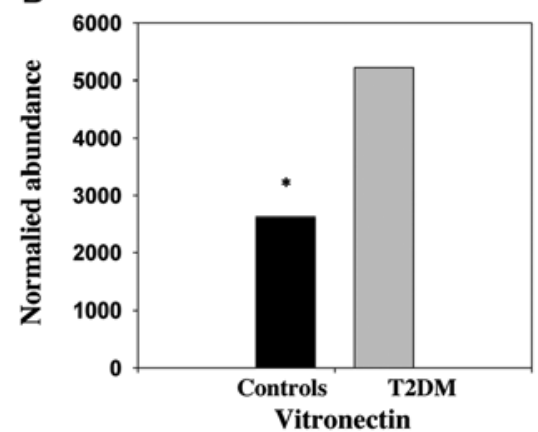

E

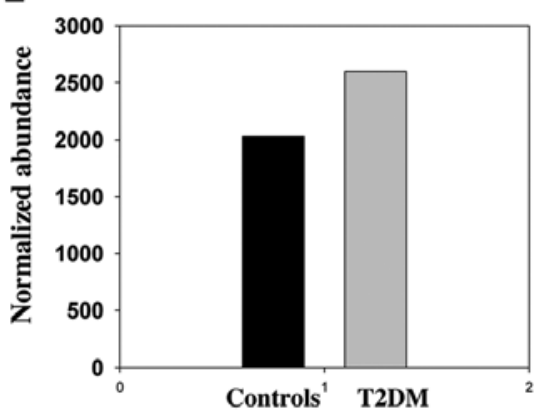

THO complex subunit 3

H

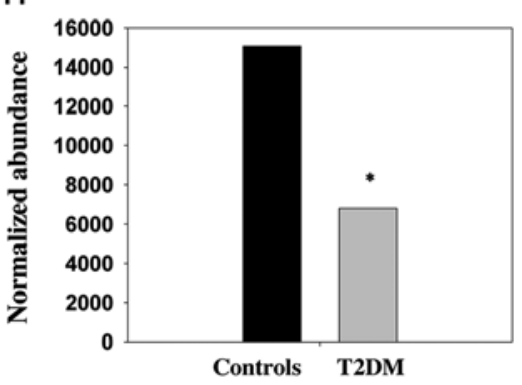

Ig $\mathrm{\gamma} \cdot \mathbf{4}$ chain $\mathrm{C}$ region

K

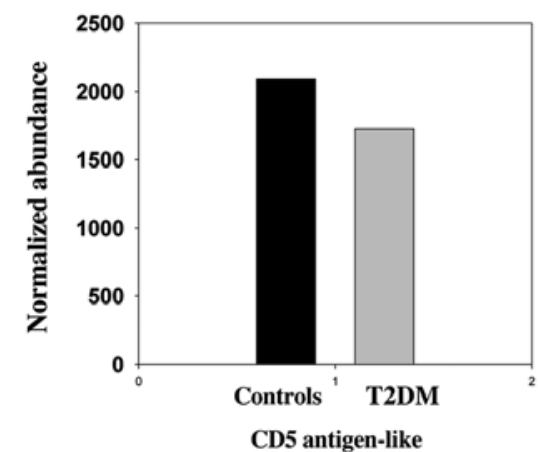

C

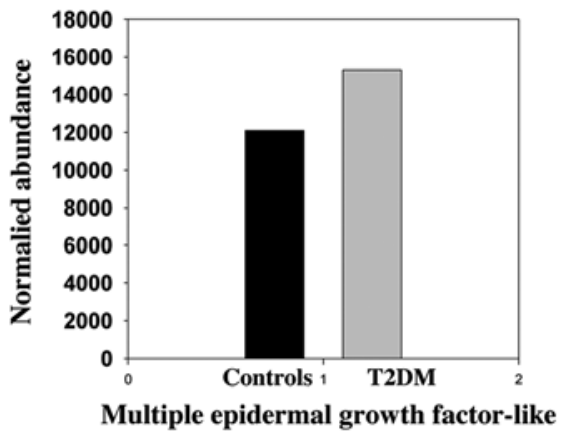

$\mathrm{F}$
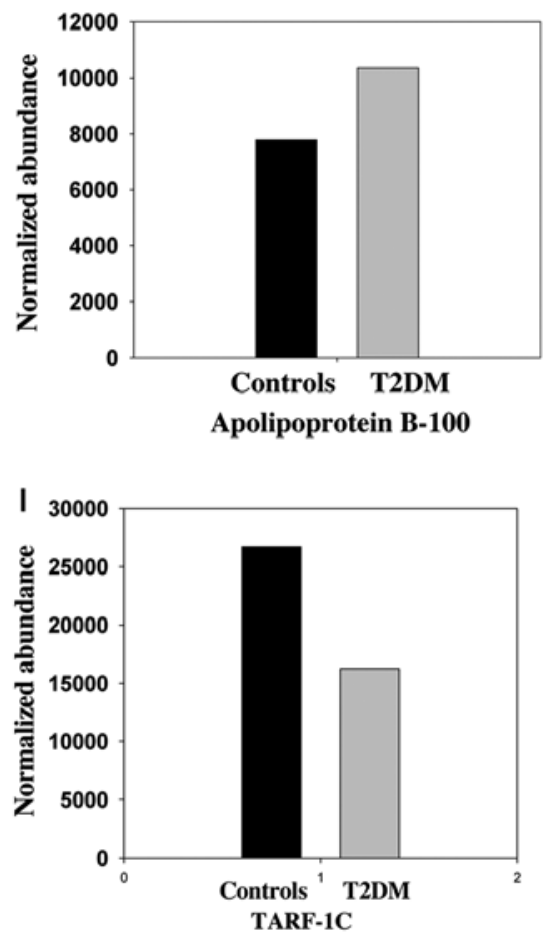

L

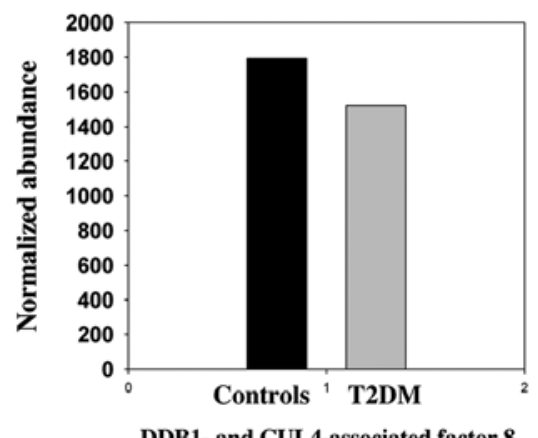

Figure 3. Histograms of the normalized abundance of selected differentially-expressed proteins (highest and lowest) identified in depleted serum samples from patients with T2DM (males and females together) and normal control subjects (males and females together). The expression changes of (A-F) upregulated and (G-L) downregulated proteins in T2DM, compared with the control, are shown. The differences between T2DM subjects and controls for the upregulated proteins, including $(\mathrm{A})$ transthyretin $(\mathrm{P}=0.018)$ and $(\mathrm{B})$ vitronectin $(\mathrm{P}<0.001)$, and downregulated proteins, including $(\mathrm{G})$ plasma protease $\mathrm{C} 1$ inhibitor $(\mathrm{P}=0.018)$ and $(\mathrm{H}) \mathrm{Ig} \gamma-4$ chain $\mathrm{C}$ region $(\mathrm{P}=0.029)$, were significant $\left({ }^{*} \mathrm{P}<0.05\right)$, according to analysis of variance. Expression levels of the other proteins $(\mathrm{C}-\mathrm{F})$ and $(\mathrm{I}-\mathrm{L})$ were not significantly different between cases and controls. The proteins were identified using label-free quantified liquid chromatography tandem mass spectrometry on Synapt G2 analysis. The expression levels of (A-L) all proteins were significantly different between T2DM subjects and controls when males and females compared separately. T2DM, type 2 diabetes mellitus.

macromolecules, carbohydrates, lipids and proteins (23). By contrast, insulin secretion is regulated by a number of metabolites, including ATP/ADP and NAD/NADH ratios, blood glucose and amino acids (24). We expected that a number of proteins are involved in DM pathological changes and their consequences. 


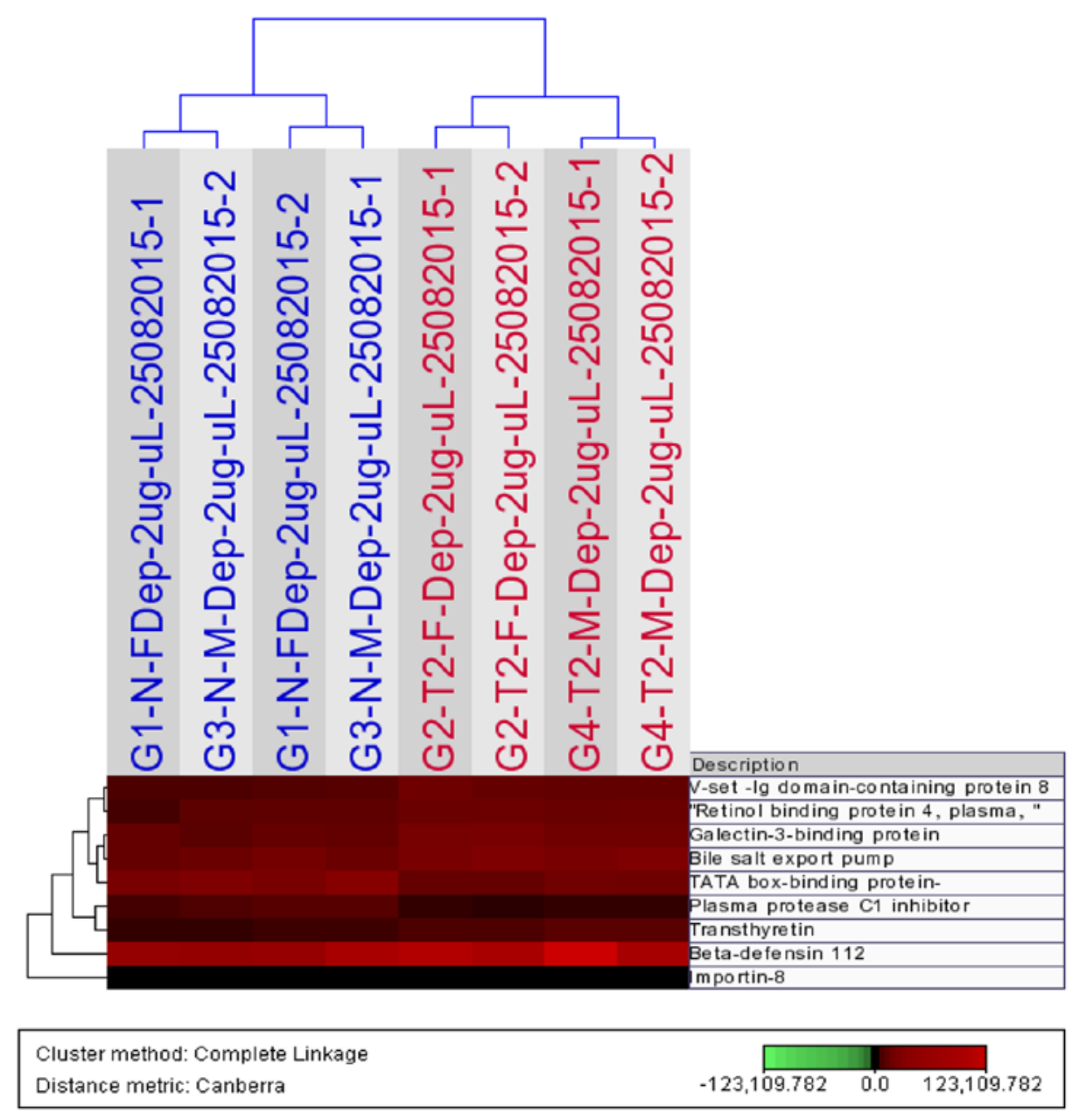

Figure 4. Hierarchical Cluster Analysis of the expression profiles of depleted serum samples using 9 proteins that differ significantly $(\mathrm{P}<0.05$, analysis of variance; maximum fold change $\geq 1.5$ ) between all controls (males and females; blue) subjects and all subjects with type 2 diabetes mellitus (red). The dendrogram was generated using the Bray Curtis Correlation distance metric and an average linkage clustering method from the J-Express Pro V1.1 software (java.sun.com).

In the present study, depleted and non-depleted sera samples were analyzed, in order to evaluate the abundance of serum proteins in T2DM. An increased number of differentially-expressed proteins was identified in depleted sera samples, compared with non-depleted sera samples (163 vs. 117 , respectively). This is not unexpected, due to the major plasma proteins (albumin and Igs) being known to mask detection of minor plasma proteins (25). Unexpectedly, the proteins whose levels of expression markedly differed between T2DM and control samples has an increased number in the non-depleted sera samples, compared with the depleted sera samples. ( 43 vs. 23 , respectively). The identification of a larger number of markedly differentially-expressed proteins in T2DM in non-depleted sera may indicate that the majority of protein markers of T2DM are not minor plasma proteins, regardless of their physiological/pathological significance. However, only 4 proteins were identified in both datasets of sera samples. Consequently, the 62 proteins that were markedly differentially-expressed in either of the 2 sets of sera samples are subsequently referred to as the 'identified proteins'.

The majority of the identified proteins were upregulated (71\%) in T2DM subjects, compared with the controls; whereas, the remaining proteins were downregulated. Using UniProt and PANTHER Class Information, the identified proteins were roughly categorized into 16 protein classes (Table IV).

The most notable observation was that the immune class of proteins was highly represented and markedly upregulated (15/18 proteins) in T2DM. These proteins mostly include the Ig chain $C$ regions $(\gamma, \alpha, \kappa, \lambda$ and $\mu)$. However, 2 Ig variable regions, Ig $\kappa$ chain V-I region AG and Protein IGKV2-28, were also identified and the latter was demonstrated to be upregulated. These 2 proteins had been previously reported to be associated with systemic lupus erythematous, an autoimmune disease (26). The role of immunity in T2DM is bimodal; since immunity could contribute to the pathology of T2DM (27) and, by contrast, the suppression of immunity is one of the major consequences of T2DM (28). Other immune proteins, including isoform 2 of Ficolin-3, $\beta$-defensin 112, Complement component C8 $\alpha$ chain and Serum amyloid P-component, were also upregulated in T2DM. Among the downregulated immune proteins were CD5 antigen-like, Ig $\gamma-4$ chain $C$ region and Ig $\kappa$ chain V-I region AG.

Out of the identified Ig chains, only 2 had been previously reported in relation to DM: The Ig $\kappa$ chain $\mathrm{C}$ region, which was demonstrated to be upregulated in T2DM (29); and Ig $\lambda$-2 chain Cregions, which has been indicated to be a site for methylglyoxal modification that associates hyperglycemia to T2DM complications (30). Of the other identified immune-associated 
Table IV. Functional classification of the differentially-expressed proteins, identified by liquid chromatography tandem mass spectrometry, in T2DM.

\begin{tabular}{|c|c|c|c|c|}
\hline No. & Class of proteins & No. of proteins & $\begin{array}{l}\text { Upregulation } \\
\text { in T2DM }\end{array}$ & $\begin{array}{c}\text { Downregulation } \\
\text { in T2DM }\end{array}$ \\
\hline 1 & Immunity (largely antibodies) & $18^{\mathrm{a}}$ & 15 & 3 \\
\hline 2 & Undefined class & 7 & 3 & 4 \\
\hline 3 & Enzyme regulator & 6 & 4 & 2 \\
\hline 4 & Hemoglobin chains and hemoglobin binding & 5 & 3 & 2 \\
\hline 5 & Cell adhesion & 4 & 4 & 0 \\
\hline 6 & Catalytic: enzymes & 4 & 2 & 2 \\
\hline 7 & Signal transduction & 4 & 2 & 2 \\
\hline 8 & Lipid metabolism and transport & 3 & 2 & 1 \\
\hline 9 & Transport & 3 & 3 & 0 \\
\hline 10 & Blood coagulation & 2 & 2 & 0 \\
\hline 11 & Regulatory & 2 & 2 & 0 \\
\hline 12 & Transcription factor & 2 & 1 & 1 \\
\hline 13 & Cytoskeletal protein & 1 & 1 & 0 \\
\hline 14 & RNA binding & 1 & 1 & 0 \\
\hline 15 & Secretory & 1 & 1 & 0 \\
\hline 16 & Spermatogensis & 1 & 0 & 1 \\
\hline Total & & 62 & 46 & 18 \\
\hline
\end{tabular}

${ }^{\mathrm{a}}$ Two proteins were both up- and downregulated, but in a different set of sera (depleted and non-depleted). Additionally, a number of proteins belong to multiple classes. T2DM, type 2 diabetes mellitus.

proteins, CD5 antigen-like was reported to be associated with atherosclerosis in T2DM (31), the serum amyloid P-component was associated with progression of retinopathy in T2DM (32) and complement component $\mathrm{C} 8 \alpha$ chain has been indicated as a biomarker for maturity-onset diabetes of the young types of DM (33). However, the remaining 13 immune-related proteins have not been previously reported in association with DM, based on the literature PubMed search.

Among the identified potential biomarker proteins, 6 were enzyme regulators, 4 of which (inter- $\alpha$-trypsin inhibitor heavy chain $\mathrm{H} 1$, plasma protease $\mathrm{C} 1$ inhibitor, thrombin light chain and inter- $\alpha$-trypsin inhibitor heavy chain H2) have not been previously reported in association with DM. Regarding the remaining 2 proteins, the protein AMBP was reported as a urinary biomarker for diabetic nephropathy (34), while the pigment epithelium-derived factor was determined to be associated with T2DM in females with gestational diabetes (35). Both proteins were determined to be upregulated in T2DM samples in the present study, compared with the control. By contrast, the 4 enzymes cDNA FLJ55673 (similar to complement factor B), multiple epidermal growth factor-like domains protein 11, ribulose-5-phosphate-3-epimerase isoform CRA_a and isoform SH-iPLA2 of $85 / 88 \mathrm{kDa}$ calcium-independent phospholipase A2, have not been previously reported in association with DM. In the present study, cDNA FLJ55673 and multiple epidermal growth factor-like domains protein 11 were upregulated, and ribulose-5-phosphate-3-epimerase isoform CRA_a and isoform SH-iPLA2, were downregulated in T2DM.

Furthermore, $2 \mathrm{Hb}$ chains (Hb subunits $\alpha$ and $\delta$ ), and a $\mathrm{Hb}$ carrier (isoform 2 of haptoglobin-related protein) were upregulated, while $2 \mathrm{Hb}$ chains ( $\mathrm{Hb}$ subunits $\beta$ and $\gamma$-2) were downregulated in T2DM, compared with the control. Of the above $\mathrm{Hb}$-associated proteins, only $\mathrm{Hb}$ subunit $\alpha$ had been previously indicated as a biomarker for T2DM (36).

The cell adhesion proteins were another class of proteins identified in the present study. Vitronectin, multiple PDZ domain protein, galectin-3-binding protein and zinc- $\alpha$-2-glycoprotein were all determined to be upregulated. Vitronectin was reported to be associated with the risk of metabolic syndrome and T2DM (37) and zinc- $\alpha$-2-glycoprotein was demonstrated to be associated with insulin resistance and T2DM (38), while the multiple PDZ domain protein was reported to be associated with DM (39). However, the galectin-3-binding protein has not been reported in association with DM previously.

Among the identified differentially-expressed proteins in $\mathrm{T} 2 \mathrm{DM}$ were 4 signal transduction proteins, including importin-8, rap guanine nucleotide exchange factor 2 , DDB1- and CUL4-associated factor 8 and suppression of tumorigenicity 5 protein. The former 2 proteins were upregulated and the latter 2 were downregulated. The suppression of tumorigenicity 5 protein and rap guanine nucleotide exchange factor 2 had been previously associated with pancreatic islets cells function $(40,41)$, while the other 2 proteins were not reported with DM.

In the present study, ceruloplasmin, transthyretin and $\alpha-1$-acid glycoprotein 2 , classified as transporters proteins, were all highly expressed in T2DM, compared with the control. This observation was consistent with previously reported data revealing the association between these proteins and DM (42-44). Similarly, 3 proteins involved in lipid 
metabolism and transport, including apolipoproteins B-100, $\mathrm{C}-\mathrm{II}$ and A-I, that were differentially-expressed in the present study (the former one was upregulated, while the latter 2 were downregulated), had previously been associated with DM and its complications (45-47).

The 2 blood coagulation-associated proteins identified in the present study, plasminogen and heparin cofactor 2, were upregulated in T2DM; however, both proteins had previously been demonstrated to be associated with DM $(48,49)$. The 2 identified regulatory proteins, V-set and Ig domain-containing protein 8 , and eukaryotic translation initiation factor 4E type 3 (eIF4E type 3) (both upregulated), had not been previously reported as DM-associated proteins. However, eIF4E type 3 is involved in renal insulin-induced protein synthesis (50).

Other identified proteins in the present study were as follows: Myosin light chain 5 (upregulated), which belongs to the cytoskeletal class of proteins and may be involved in endothelial tissue dysfunctions in DM (51); bile salt export pump, a secretory protein, which was highly expressed in T2DM samples and has been considered to be involved in the hepatotoxicity of troglitazone, an anti-diabetes agent (52); and THO complex subunit 3, an RNA-binding protein (53), which was upregulated in the present study, but had not been previously associated with DM.

Classes of 7 proteins were not identified: TATA box-binding protein-associated factor RNA polymerase I subunit C, intraflagellar transport protein 122 homolog, isoform 4 of coiled-coil domain-containing protein 17, procollagen $\mathrm{C}$-endopeptidase enhancer 2, Ugl-Y3, protein IGKV3-11 and clusterin $\beta$ chain. These proteins had also not been previously described in association with DM and their observed expression changes in T2DM in the present study was a novel observation. However, clusterin gene polymorphism had previously been determined to be associated with T2DM (54).

Finally, to validate the observations of LC-MS/MS analysis, 2 of the identified proteins were analyzed by ELISA in a relatively larger sample size from the same setting. Additionally, the results confirmed the differential expression of these proteins in T2DM (data not published). Notably, in the future, the remaining 35 identified novel proteins will be evaluated using a large sample size from the region.

In conclusion, in the present study, 62 markedly differentially-expressed proteins were identified by LC-MS/MS in Bahraini patients with T2DM. These proteins could be grouped functionally into 16 classes, the largest being that of immune-associated proteins. The majority of the identified proteins were upregulated in T2DM. The fact that 25 of the identified proteins have been previously implicated with DM is a validation of the present data. The remaining 37 proteins need to be validated in larger samples in order to access their potential clinical usefulness in DM; however, their association with T2DM in the present study is a novel finding. A detailed investigation of each of the 37 proteins may provide insight into the understanding of the pathogenesis and pathophysiology of T2DM and insulin resistance, since each of these proteins have a known physiological function. Finally, the global blood protein profile in T2DM, as revealed by LC-MS/MS proteomic analysis, demonstrated increased protein synthesis, including immune proteins.

\section{Acknowledgments}

The authors would like to express their gratitude to the clinicians in SMC, and Arad, Al-Dair and Sheikh Salman Health Centers (Muharraq, Bahrain). Additionally, there is special thanks for Dr Jaffar Abbas (Arad Health Center, Muharraq, Bahrain), who assisted in patients' recruitment, data collection and biochemical analysis. A sincere appreciation is extended to the staff of Proteomics Unit - King Faisal Specialist Hospital and Research Center (Riyadh, Saudi Arabia) for assistance in the proteomics work.

\section{Funding}

No funding received.

\section{Availability of data and materials}

The datasets used and/or analyzed during the current study are available from the corresponding author on reasonable request.

\section{Authors' contributions}

RAA, AA and HAG developed the research idea and study design. RAA collected the samples. RAA, AA and ZS conducted the laboratory work. RAA, AA, AAAA and HAG conducted the statistical analysis. RAA, AA and HAG drafted the manuscript and all authors contributed to the final version of the manuscript.

\section{Ethics approval and consent to participate}

All procedures performed in studies involving human participants were conducted in accordance with the ethical standards of Arabian Gulf University (Manama, Bahrain) and the Research Committee of SMC, and with the 1964 Helsinki Declaration and its later amendments. Verbal informed consent was obtained from all study subjects.

\section{Patient consent for publication}

The patients consented for publication.

\section{Competing interests}

All authors declare that they have no competing interests.

\section{References}

1. American Diabetes Association: Diagnosis and classification of diabetes mellitus. Diabetes Care 32 (Suppl 1): S62-S67, 2009.

2. World Health Organization: Global Report on Diabetes. World Health Organization, Geneva, Swizerland, 2016. http://apps.who. int/iris/bitstream/10665/204871/1/9789241565257_eng.pdf.

3. Al-Mahroos F: Diabetes mellitus in the Arabian peninsula. Ann Saudi Med 20: 111-112, 2000.

4. International Diabetes Federation: IDF Diabetes Atlas. 7th edition, IDF, Brussels, Belgium, 2015.

5. Van JA, Scholey JW and Konvalinka A: Insights into Diabetic Kidney Disease Using Urinary Proteomics and Bioinformatics. J Am Soc Nephrol 28: 1050-1061, 2017.

6. Cottrell JS: Protein identification using MS/MS data. J Proteomics 74: 1842-1851, 2011. 
7. Bukowiecka-Matusiak M, Chmielewska-Kassassir M, Szczesna D and Wozniak LA: Metabolomic insight into lipid and protein profile in diabetes using mass spectrometry. Mini Rev Med Chem 16: 1167-1174, 2016.

8. Doria A, Patti ME and Kahn CR: The emerging genetic architecture of type 2 diabetes. Cell Metab 8: 186-200, 2008.

9. Kahn CR: Banting Lecture. Insulin action, diabetogenes, and the cause of type II diabetes. Diabetes 43: 1066-1084, 1994.

10. Knox SS: From 'omics' to complex disease: A systems biology approach to gene-environment interactions in cancer. Cancer Cell Int 10: 11, 2010.

11. PonomarenkoEA,Poverennaya EV,Ilgisonis EV,Pyatnitskiy MA, Kopylov AT, Zgoda VG, Lisitsa AV and Archakov AI: The size of the human proteome: The width and depth. Int J Anal Chem 2016: 7436849, 2016.

12. DeFronzo RA, Ferrannini E, Zimmet $P$ and George KM and Alberti M (eds): International Textbook of Diabetes Mellitus. 4th edition. John Wiley and Sons, New York, NY, 2015.

13. Anderson NL and Anderson NG: The human plasma proteome: History, character, and diagnostic prospects. Mol Cell Proteomics 1: 845-867, 2002.

14. Anderson NL, Anderson NG, Pearson TW, Borchers CH, Paulovich AG, Patterson SD, Gillette M, Aebersold R and Carr SA: A human proteome detection and quantitation project. Mol Cell Proteomics 8: 883-886, 2009.

15. World Health Organisation: Definition and diagnosis of diabetes mellitus and intermediate hyperglycemia: Report of a WHO/IDF consultation. World Health Organisation, Geneva, Swizerland, 2002. https://www.idf.org/webdata/docs/WHO_IDF_definition_ diagnosis_of_diabetes.pdf.

16. Bradford $\bar{M} \bar{M}$ : A rapid and sensitive method for the quantitation of microgram quantities of protein utilizing the principle of protein-dye binding. Anal Biochem 72: 248-254, 1976.

17. Alaiya A, Fox J, Bobis S, Matic G, Shinwari Z, Barhoush E, Márquez M, Nilsson S and Holmberg AR: Proteomic analysis of soft tissue tumor implants treated with a novel polybisphosphonate. Cancer Genomics Proteomics 11: 39-49, 2014.

18. Alaiya A, Assad L, Alkhafaji D, Shinwari Z, Almana H, Shoukri M, Alkorbi L, Ibrahim HG, Abdelsalam MS, Skolnik E, et al: Proteomic analysis of Class IV lupus nephritis. Nephrol Dial Transplant 30: 62-70, 2015.

19. Li GZ, Vissers JP, Silva JC, Golick D, Gorenstein MV and Geromanos SJ: Database searching and accounting of multiplexed precursor and product ion spectra from the data independent analysis of simple and complex peptide mixtures. Proteomics 9: 1696-1719, 2009

20. Alaiya AA, Aljurf M, Shinwari Z, Almohareb F, Malhan H, Alzahrani H, Owaidah T, Fox J, Alsharif F, Mohamed SY, et al: Protein signatures as potential surrogate biomarkers for stratification and prediction of treatment response in chronic myeloid leukemia patients. Int J Oncol 49: 913-933, 2016

21. Apweiler R, Bairoch A, Wu CH, Barker WC, Boeckmann B, Ferro S, Gasteiger E, Huang H, Lopez R, Magrane M, et al: UniProt: The universal protein knowledgebase. Nucleic Acids Res 32: D115-D119, 2004

22. Weir GC and Leahy JL (eds): Pathogenesis of non-insulindependent (type II) diabetes mellitus. In: Joslin's Diabetes Mellitus. 13th edition. Lea and Febiger, Philadelphia, PA, pp240-264, 1994.

23. Saltiel AR, Kahn CR: Insulin signalling and the regulation of glucose and lipid metabolism. Nature 13: 799-806, 2001.

24. Meglasson MD and Matschinsky FM: Pancreatic islet glucose metabolism and regulation of insulin secretion. Diabetes Metab Rev 2: 163-214, 1986

25. Gersten DM, Khirabadi BS, Kurian P, Ledley RS, Mahany T, Ramey ER and Ramwell PW: Albumin obscures sex differences in blood protein patterns of rats and humans. Biochem J 191: 869-872, 1980

26. Al Kindi MA, Chataway TK, Gilada GA, Jackson MW, Goldblatt FM, Walker JG, Colella AD and Gordon TP: Serum SmD autoantibody proteomes are clonally restricted and share variable-region peptides. J Autoimmun 57: 77-81, 2015.

27. Brooks-Worrell B and Palmer JP: Immunology in the Clinic Review Series; focus on metabolic diseases: development of islet autoimmune disease in type 2 diabetes patients: potential sequelae of chronic inflammation. Clin Exp Immunol 167: 40-46, 2012.

28. Geerlings SE and Hoepelman AI: Immune dysfunction in patients with diabetes mellitus (DM). FEMS Immunol Med Microbiol 26: 259-265, 1999.
29. Murri M, Insenser M, Bernal-Lopez MR, Perez-Martinez P, Escobar-Morreale HF and Tinahones FJ: Proteomic analysis of visceral adipose tissue in pre-obese patients with type 2 diabetes. Mol Cell Endocrinol 376: 99-106, 2013

30. Kimzey MJ, Kinsky OR, Yassine HN, Tsaprailis G, Stump CS, Monks TJ and Lau SS: Site specific modification of the human plasma proteome by methylglyoxal. Toxicol Appl Pharmacol 289: 155-162, 2015.

31. Lepedda AJ, Lobina O, Rocchiccioli S, Nieddu G, Ucciferri N, De Muro P, Idini M, Nguyen HQ, Guarino A, Spirito R and Formato M: Identification of differentially expressed plasma proteins in atherosclerotic patients with type 2 diabetes. J Diabetes Complications 30: 880-886, 2016.

32. Yang HS, Woo JE, Lee SJ, Park SH and Woo JM: Elevated plasma pentraxin 3 levels are associated with development and progression of diabetic retinopathy in Korean patients with type 2 diabetes mellitus. Invest Ophthalmol Vis Sci 55: 5989-5997, 2014.

33. Karlsson E, Shaat N and Groop L: Can complement factors 5 and 8 and transthyretin be used as biomarkers for MODY 1 (HNF4A-MODY) and MODY 3 (HNF1A-MODY)? Diabet Med 25: 788-791, 2008.

34. Zubiri I, Posada-Ayala M, Sanz-Maroto A, Calvo E, Martin-Lorenzo M, Gonzalez-Calero L, de la Cuesta F, Lopez JA, Fernandez-Fernandez B, Ortiz A, et al: Diabetic nephropathy induces changes in the proteome of human urinary exosomes as revealed by label-free comparative analysis. J Proteomics 96: 92-102, 2014.

35. Li TH, Qiu CJ, Yu XJ, Liu DD, Zhou PF and Wu L: Increased serum pigment epithelium-derived factor in women with gestational diabetes is associated with type 2 diabetes. Int $\mathbf{J}$ Endocrinol 2015: 346938, 2015.

36. Kolberg JA, Gerwien RW, Watkins SM, Wuestehube LJ and Urdea M: Biomarkers in Type 2 diabetes: Improving risk stratification with the PreDx ${ }^{\circledR}$ Diabetes Risk Score. Expert Rev Mol Diagn 11: 775-792, 2011.

37. Alessi MC, Nicaud V, Scroyen I, Lange C, Saut N, Fumeron F, Marre M, Lantieri O, Fontaine-Bisson B, Juhan-Vague I, et al; DESIR Study Group: Association of vitronectin and plasminogen activator inhibitor-1 levels with the risk of metabolic syndrome and type 2 diabetes mellitus. Results from the D.E.S.I.R. prospective cohort. Thromb Haemost 106: 416-422, 2011.

38. Yang M, Liu R, Li S, Luo Y, Zhang Y, Zhang L, Liu D, Wang Y, Xiong Z, Boden G, et al: Zinc- $\alpha 2$-glycoprotein is associated with insulin resistance in humans and is regulated by hyperglycemia, hyperinsulinemia, or liraglutide administration: Cross-sectional and interventional studies in normal subjects, insulin-resistant subjects, and subjects with newly diagnosed diabetes. Diabetes Care 36: 1074-1082, 2013

39. Lee JH, Volinic JL, Banz C, Yao KM and Thomas MK: Interactions with $\mathrm{p} 300$ enhance transcriptional activation by the PDZ-domain coactivator Bridge-1. J Endocrinol 187: 283-292, 2005.

40. Gupta RK, Gao N, Gorski RK, White P, Hardy OT, Rafiq K, Brestelli JE, Chen G, Stoeckert CJ Jr and Kaestner KH: Expansion of adult beta-cell mass in response to increased metabolic demand is dependent on HNF-4alpha. Genes Dev 21: 756-69, 2007

41. Kelly P, Bailey CL, Fueger PT, Newgard CB, Casey PJ, Kimple ME. Rapl promotes multiple pancreatic islet cell functions and signals through mammalian target of rapamycin complex 1 to enhance proliferation. J Biol Chem 285: 15777-15785, 2010.

42. Christiansen MS, Iversen K, Larsen CT, Goetze JP, Hommel E, Mølvig J, Pedersen BK, Magid E and Feldt-Rasmussen B: Increased urinary orosomucoid excretion: A proposed marker for inflammation and endothelial dysfunction in patients with type 2 diabetes. Scand J Clin Lab Invest 69: 272-281, 2009.

43. Pullakhandam R, Palika R, Ghosh S and Reddy GB: Contrasting effects of type 2 and type 1 diabetes on plasma RBP4 levels: The significance of transthyretin. IUBMB Life 64: 975-982, 2012

44. Gluhovschi C, Gluhovschi G, Petrica L, Timar R, Velciov S, Ionita I, Kaycsa A and Timar B: Urinary Biomarkers in the Assessment of Early Diabetic Nephropathy. J Diabetes Res 2016: 4626125,2016

45. Watts GF, Ooi EM and Chan DC: Therapeutic regulation of apoB100 metabolism in insulin resistance in vivo. Pharmacol Ther 123: 281-291, 2009.

46. Kei AA, Filippatos TD, Tsimihodimos V and Elisaf MS: A review of the role of apolipoprotein C-II in lipoprotein metabolism and cardiovascular disease. Metabolism 61: 906-921, 2012. 
47. Rye KA, Barter PJ and Cochran BJ: Apolipoprotein A-I interactions with insulin secretion and production. Curr Opin Lipidol 27: 8-13, 2016.

48. Yarmolinsky J, Bordin Barbieri N, Weinmann T,Ziegelmann PK, Duncan BB and Inês Schmidt M: Plasminogen activator inhibitor-1 and type 2 diabetes: a systematic review and meta-analysis of observational studies. Sci Rep 6: 17714, 2016.

49. Hasegawa Y and Ishigaki Y: Heparin Cofactor II: A novel plausible link of obesity and diabetes with thrombosis. J Atheroscler Thromb 24: 1202-1203, 2017.

50. Bhandari BK, Feliers D, Duraisamy S, Stewart JL, Gingras AC, Abboud HE, Choudhury GG, Sonenberg N and Kasinath BS: Insulin regulation of protein translation repressor 4E-BP1, an eIF4E-binding protein, in renal epithelial cells. Kidney Int 59: 866-875, 2001.

51. Rigor RR, Shen Q, Pivetti CD, Wu MH and Yuan SY: Myosin light chain kinase signaling in endothelial barrier dysfunction. Med Res Rev 33: 911-933, 2013.

52. Funk C, Ponelle C, Scheuermann G and Pantze M: Cholestatic potential of troglitazone as a possible factor contributing to troglitazone-induced hepatotoxicity: In vivo and in vitro interaction at the canalicular bile salt export pump (Bsep) in the rat. Mol Pharmacol 59: 627-635, 2001.
53. Strässer K, Masuda S, Mason P, Pfannstiel J, Oppizzi M, Rodriguez-Navarro S, Rondón AG, Aguilera A, Struhl K, Reed R and Hurt E: TREX is a conserved complex coupling transcription with messenger RNA export. Nature 417: 304-308, 2002.

54. Daimon M, Oizumi T, Karasawa S, Kaino W, Takase K, Tada K, Jimbu Y, Wada K, Kameda W, Susa S, et al: Association of the clusterin gene polymorphisms with type 2 diabetes mellitus. Metabolism 60: 815-822, 2011.

This work is licensed under a Creative Commons Attribution-NonCommercial-NoDerivatives 4.0 International (CC BY-NC-ND 4.0) License. 